\title{
Statistical appendix
}

\section{Digest of data on the rheumatic diseases}

\author{
3. Handicap and disability, and international comparisons of morbidity and mortality
}

\author{
PREPARED IN 1971 BY THE ARTHRITIS AND RHEUMATISM COUNCIL \\ FIELD UNIT FOR EPIDEMIOLOGICAL INVESTIGATIONS
}

This report considers:

(1) Data on morbidity and on handicapped persons on the General Classes Register derived from the Report of the Department of Health and Social Security (DHSS) for the year 1967-1968, supplemented by additional information provided by the Department.

(2) Data on Registered Disabled Persons at April, 1968, supplied by the Department of Employment and Productivity (DEP).

(3) Mortality data derived from the Registrar General's Statistical Review of England and Wales and the Annual Report of the Registrar General for Scotland for the year 1968 .

(4) International mortality data derived from Volume I of the World Health Statistics Annual for 1966.

Arthritis and rheumatism consist of those conditions defined as rheumatic complaints by a WHO Working Group on the Epidemiology of Rheumatic Complaints, 1970; osteomyelitis is not included, but Paget's disease, osteochondrosis, and other diseases of bone are included (Benn, 1971).

\section{(i) Morbidity in Great Britain}

Sickness and injury incapacity in the year ended June 1, 1968, are shown in Table I (opposite). Insured persons lost 37.6 million days from work through rheumatic complaints. This was 11.7 per cent. of all sickness incapacity, and was eight times greater than the work loss due to industrial stoppages in 1968 (4.7 million days-Annual Abstract of Statistics, 1968). In everyday terms, this was equivalent to every insured man or woman losing about 2 days (1.8 days) through rheumatism during the year.

In terms of individuals, almost a million spells of incapacity due to rheumatic complaints started during the year (earlier reports have quoted spells current rather than spells started). These accounted for 10.6 per cent. of all spells, and were exceeded in magnitude only by accidents and influenza (11.5 and 14.9 per cent, respectively). Put differently, the same total would have been produced if one insured man in every twenty and one insured woman in every 34 had started a spell of sickness incapacity due to rheumatism.

The general pattern of incapacity appears to con尺̊ tinue earlier trends (Statistical Appendix, 1970) Women continue to lose more time than do men witk the same conditions. Perhaps most worthy of com= ment is the tendency for the estimated mean duration of spells to increase.

\section{(ii) Handicap and Disability}

There were 22,638 men, 5,248 women, and 59 boys and girls suffering from arthritis and rheumatism on the Register of Disabled Persons (DP) for Great Britain at April 15, 1968. These individuals with rheumatic complaints formed 4.3 per cent. of all persons on the DP Register, the proportion being slightly lower in men (4.0 per cent.), slightly higher in women (5.8 per cent.), and much lower in young persons $(1.5$ per cent.).

Handicapped persons on the General Classes Register yield a more representative picture than either sickness incapacity or the DP Register, as they include persons aged 65 years and over, as well as a much larger proportion of women. For a variety of reasons this register is still in a state of flux (Sainsbury, 1970). The number of persons registered has increased by approximately 10 per cent. per annum during the last 3 years for which data are available, and arthritis and rheumatism have been responsible for an increasing proportion of these handicaps, the annual increase in the proportion being 1.2 per cent.

Increasing regional autonomy makes it more difficult to report exhaustive data, so that the information 
Table I Spells of incapacity, days of certified incapacity, and average duration of spells due to rheumatic complaints in Great Britain in the year ended June 1, 1968, by sex

Derived from a 5 per cent. sample of claimants

\begin{tabular}{|c|c|c|c|c|c|c|c|}
\hline \multirow[t]{2}{*}{ Incapacity } & \multirow{2}{*}{$\begin{array}{l}\text { Certified cause } \\
\text { (Rubrics of International } \\
\text { Statistical Classification } \\
\text { of Diseases, 1955) }\end{array}$} & \multicolumn{3}{|l|}{ Males } & \multicolumn{3}{|l|}{ Females* } \\
\hline & & $\begin{array}{l}\text { Spells } \\
\left(\times 10^{-3}\right)\end{array}$ & $\begin{array}{l}\text { Days of } \\
\text { incapacity } \\
\left(\times 10^{-6}\right)\end{array}$ & $\begin{array}{l}\text { Estimated } \\
\text { mean } \\
\text { duration } \\
\text { of spells } \\
\text { (days) } \dagger\end{array}$ & $\begin{array}{l}\text { Spells } \\
\left(\times 10^{-3}\right)\end{array}$ & $\begin{array}{l}\text { Days of } \\
\text { incapacity } \\
\left(\times 10^{-6}\right)\end{array}$ & $\begin{array}{l}\text { Estimated } \\
\text { mean } \\
\text { duration } \\
\text { of spells } \dagger \\
\text { (days) }\end{array}$ \\
\hline \multirow[t]{6}{*}{$\begin{array}{l}\text { Sickness } \\
\text { (spells } \\
\text { started) }\end{array}$} & $\begin{array}{l}\text { Gout (288) } \\
\text { Sciatica (363) } \\
\text { Rheumatic fever (400-402) } \\
\text { Arthritis (720-725) } \\
\text { Rheumatism (726-727) except } \\
\text { lumbago }\end{array}$ & $\begin{array}{r}12 \cdot 9 \\
48 \cdot 6 \\
0 \cdot 6 \\
98 \cdot 8 \\
222 \cdot 9\end{array}$ & $\begin{array}{r}0 \cdot 33 \\
1 \cdot 71 \\
0 \cdot 08 \\
10 \cdot 84 \\
4 \cdot 32\end{array}$ & $\begin{array}{r}25 \cdot 5 \\
35 \cdot 3 \\
128 \cdot 7 \\
109 \cdot 8 \\
19 \cdot 4\end{array}$ & $\begin{array}{r}0 \cdot 2 \\
7 \cdot 4 \\
0 \cdot 1 \\
17 \cdot 1 \\
45 \cdot 2\end{array}$ & $\begin{array}{l}0 \cdot 01 \\
0 \cdot 28 \\
0 \cdot 08 \\
4 \cdot 09 \\
1 \cdot 20\end{array}$ & $\begin{array}{r}38 \cdot 4 \\
37 \cdot 5 \\
238 \cdot 6 \\
26 \cdot 5\end{array}$ \\
\hline & $\begin{array}{l}\text { Lumbago }(726 \cdot 0) \\
\text { Internal derangement of knee } \\
(734)\end{array}$ & $\begin{array}{r}129.9 \\
12.0\end{array}$ & $\begin{array}{l}2.29 \\
0.53\end{array}$ & $\begin{array}{l}17 \cdot 6 \\
44 \cdot 5\end{array}$ & $\begin{array}{r}17 \cdot 4 \\
1 \cdot 0\end{array}$ & $\begin{array}{l}0.35 \\
0.06\end{array}$ & $\begin{array}{l}19.9 \\
55.6\end{array}$ \\
\hline & $\begin{array}{l}\text { Displacement of intervertebral } \\
\text { disc (735) }\end{array}$ & $66 \cdot 1$ & $3 \cdot 52$ & $53 \cdot 3$ & $8 \cdot 0$ & 0.75 & $94 \cdot 0$ \\
\hline & $\begin{array}{l}\text { Synovitis, bursitis, etc. }(741-742) \\
\text { Ankylosis, etc. }(737,745-749) \\
\text { Other bone disease }(731-733 \text {, } \\
736,738,740,743,744)\end{array}$ & $\begin{array}{r}35 \cdot 4 \\
2 \cdot 2 \\
17 \cdot 9\end{array}$ & $\begin{array}{l}0 \cdot 82 \\
0 \cdot 21 \\
1 \cdot 58\end{array}$ & $\begin{array}{l}23 \cdot 1 \\
94 \cdot 4 \\
88 \cdot 3\end{array}$ & $\begin{array}{l}9 \cdot 2 \\
0 \cdot 9 \\
3 \cdot 7\end{array}$ & $\begin{array}{l}0 \cdot 24 \\
0 \cdot 11 \\
0 \cdot 45\end{array}$ & $\begin{array}{r}26 \cdot 2 \\
119 \cdot 4 \\
121 \cdot 6\end{array}$ \\
\hline & Ill-defined (787) & $105 \cdot 1$ & $2 \cdot 10$ & $20 \cdot 0$ & $24 \cdot 0$ & 0.55 & $23 \cdot 1$ \\
\hline & Total sickness & $752 \cdot 4$ & $28 \cdot 33$ & $37 \cdot 7$ & $134 \cdot 2$ & $8 \cdot 17$ & $60 \cdot 8$ \\
\hline \multirow{6}{*}{$\begin{array}{l}\text { Injury } \\
\text { (spells } \\
\text { terminated) }\end{array}$} & $\begin{array}{l}\text { Arthritis and Rheumatism } \\
(720-727)\end{array}$ & $2 \cdot 1$ & 0.06 & $33 \cdot 7$ & $0 \cdot 2$ & 0.01 & $62 \cdot 5$ \\
\hline & $\begin{array}{l}\text { Internal derangement of knee } \\
(734)\end{array}$ & 0.6 & 0.04 & $76 \cdot 9$ & - & - & - \\
\hline & $\begin{array}{l}\text { Displacement of intervertebral } \\
\text { disc (735) }\end{array}$ & $8 \cdot 3$ & 0.45 & $60 \cdot 0$ & 0.9 & 0.07 & $77 \cdot 8$ \\
\hline & $\begin{array}{l}\text { Synovitis, bursitis, etc. (741-742) } \\
\text { Beat knee (Prescribed disease 32) } \\
\text { Beat elbow (Prescribed } \\
\text { disease 33) }\end{array}$ & $\begin{array}{l}5 \cdot 3 \\
3 \cdot 9 \\
0 \cdot 6\end{array}$ & $\begin{array}{l}0 \cdot 14 \\
0 \cdot 11 \\
0 \cdot 02\end{array}$ & $\begin{array}{l}28 \cdot 5 \\
33 \cdot 3 \\
47 \cdot 7\end{array}$ & $\begin{array}{r}0.7 \\
0.2 \\
-\end{array}$ & $\begin{array}{l}0.03 \\
0.01 \\
-\end{array}$ & $\begin{array}{l}51 \cdot 7 \\
55.6 \\
-\end{array}$ \\
\hline & $\begin{array}{l}\text { Inflammation of wrist, etc. } \\
\text { (Prescribed disease 34) }\end{array}$ & $3 \cdot 3$ & 0.07 & $23 \cdot 6$ & $1 \cdot 7$ & 0.07 & $42 \cdot 2$ \\
\hline & Total injury & $24 \cdot 1$ & $0 \cdot 89$ & $41 \cdot 6$ & $3 \cdot 7$ & $0 \cdot 19$ & $52 \cdot 9$ \\
\hline Total sickness & and injury & $776 \cdot 5$ & $29 \cdot 22$ & $37 \cdot 8$ & $137 \cdot 9$ & $8 \cdot 36$ & $60 \cdot 7$ \\
\hline
\end{tabular}

* Less importance can be attached to the data for females because the population at risk is limited in coverage-about three-quarters of all married women in employment elect not to be insured for sickness benefit.

+ Days of incapacity divided by spells started during year. This estimate is greater than previously quoted indexes of average duration because the denominator is less (i.e. spells started versus those current); however, it is a less biased estimate.

in Table II (overleaf) relates to England only (i.e. Wales and Scotland are not included). At December 31,1968 , it was estimated that 53,445 handicapped individuals on the register were suffering from arthritis and rheumatism. This may be compared with the DP Register for England, on which approximately 24,000 persons were suffering from arthritis and rheumatism. However, one cannot establish the relationship between these registers directly, because they were established for different purposes and are administered by different government departments.

Individuals with rheumatic complaints constituted 28.4 per cent. of all handicapped persons on the General Classes Register. More striking, though, is the burden in the elderly, where arthritis and rheumatism are by far the biggest causes of handicap, accounting for 43.5 per cent. of the total. These data also provide some indication of the frequency of suffering in women, who are seriously under-represented in information from other sources. In those aged 65 years and more, women outnumber men on the register in the ratio of $2: 1$.

\section{(iii) The Costs of Rheumatic Complaints}

National Health Service expenditure for 1967-1968 has been reviewed (Office of Health Economics, 1969 ), showing that $£ 28$ million were spent on hospital in-patient services for those with diseases of bones and organs of movement. This was 4.6 per cent. 
Table II Persons suffering from arthritis and rheumatism on the General Classes Register of Handicapped Persons for England at December 31, 1968, by age

\begin{tabular}{|c|c|c|c|}
\hline $\begin{array}{l}\text { Age } \\
\text { (yrs) }\end{array}$ & $\begin{array}{l}\text { Persons with } \\
\text { arthritis and } \\
\text { rheumatism } \\
\left.\text { (estimated }{ }^{*}\right)\end{array}$ & $\begin{array}{l}\text { Proportion of } \\
\text { all arthritis } \\
\text { and } \\
\text { rheumatism } \\
\text { (per cent.) }\end{array}$ & $\begin{array}{l}\text { Proportion of } \\
\text { all major } \\
\text { handicaps in } \\
\text { age group } \\
\text { (per cent.) }\end{array}$ \\
\hline $\begin{array}{l}<16 \\
16-29 \\
30-49 \\
50-64 \\
65+\end{array}$ & $\begin{array}{r}53 \\
372 \\
2,774 \\
12,527 \\
37,719\end{array}$ & $\begin{array}{r}0 \cdot 1 \\
0 \cdot 7 \\
5 \cdot 2 \\
23 \cdot 4 \\
70 \cdot 6\end{array}$ & $\begin{array}{r}1 \cdot 0 \\
2 \cdot 8 \\
9 \cdot 5 \\
23 \cdot 1 \\
43 \cdot 5\end{array}$ \\
\hline All ages & 53,445 & $100 \cdot 0$ & $28 \cdot 4$ \\
\hline
\end{tabular}

* Only estimated numbers can be derived because data specific for major handicaps are available only from most authorities. The estimate is computed by applying the proportion these form of all handicaps to the total for all handicaps reported by all authorities.

of the total for hospital services, which is commensurate with the proportion formed by these diseases of all estimated discharges and deaths from hospitals in England and Wales-3.3 per cent. (DHSS and OPCS, 1970). A further $£ 16.3$ million were spent on domiciliary goods and services, yielding a total of $£ 44.3$ million, which was 4.4 per cent. of all NHS expenditure.

\section{(iv) Mortality in Great Britain}

At first sight the 2,563 persons who were certified as having died from one of the rheumatic complaints (Table III) appears to represent an appreciable increase on previous years. However, this impression is largely due to the introduction of the 8th (1965) Revision of the International Classification of Diseases (ICD), which for the first time includes diffuse diseases of connective tissue in the section on disorders of the musculoskeletal system. In fact, the pattern of deaths does not differ significantly from earlier years.

\section{(v) Morbidity in Selected Countries}

The countries reported in Table IV have been selected entirely on the basis of ready availability of reasonably comparable data. The gaps in the Table underline the difficulties that result from inconsistencies in the style of reporting by different governmental agencies, even though a common framework, the ICD, is available. As there is no single satisfactory index of morbidity, a number of different indicators is reported.

Too much should not be made of the observed differences in Table IV (opposite). The striking point to emerge is that Great Britain is by no means unique in its burden of suffering from rheumatic complaints. These conditions occur with similar frequency in
Table III Deaths from rheumatic complaints in Great Britain in 1968, by sex

\section{Complaint}

(Rubrics of International Statistical

Classification of Diseases, 1965)

Gout (274)

Sciatica (353)

Rheumatic fever (390-392)

Arthritis (710-715)

(Rheumatoid arthritis and allied conditions (712)*

Polymyositis and dermatomyositis (716)

Rheumatism (717)

Internal derangement of joints (724)

Displacement of intervertebral disc (725)

Synovitis, bursitis, etc. (731)

Diffuse diseases of connective tissue (734)

Ankylosis and other acquired deformities $(727,735-738)$

Other diseases of bones and joints (721-723, 726, 728-730, 733)

Ill-defined (787)

Total

Sex

Male

37

0

12

435

(287)

180

$\frac{0}{754} \frac{0}{1809}$

* Values specific for rheumatoid arthritis and allied conditions shown in parentheses because they are included in the figures immediatel above, for arthritis as a whole.

other European countries and in the U.S.A., account ing for something like a tenth of all sickness incapacity, a slightly larger proportion of disability or invalidity, and between 3 and 4 per cent. of all hospital discharges. The magnitude of this common burden makes the continued lack of involvement with the problem by the World Health Organization the more surprising.

Arthritis and rheumatism account for slightly more than half all sickness incapacity due to diseases of the bones and organs of movement, but, as would be expected, they are responsible for a larger proportion of disability or invalidity.

\section{(vi) Mortality in Selected Countries (Table V)}

Because the case fatality rate is generally low, mortality data in rheumatoid arthritis (RA) are usually regarded as unrepresentative and therefore worthy of little attention. However, in the absence of evidence suggesting differences in case fatality rates between different countries, death rates can be of value as a rough check on other estimates of disease frequency. One would expect a crude parallelism to exist between mortality and estimates of disease prevalence.

Kellgren (1966) and Wood (1970) have drawn attention to the difficulty in comparing estimates of RA from different countries. Most noteworthy were data from Japan, which indicated a low overall prevalence and a gross relative excess of female 
Table IV Various indices of morbidity due to rheumatic complaints in selected countries* Morbidity due to rheumatic complaints expressed as percentage of that due to all causes

\begin{tabular}{|c|c|c|c|c|c|c|c|c|}
\hline $\begin{array}{l}\text { Complaint } \\
\text { (Rubrics of International } \\
\text { Statistical Classification } \\
\text { of Diseases, 1965) }\end{array}$ & Index of Morbidity & $\operatorname{Sex}$ & Austria & Czechoslovakia & Finland & Sweden & $U K \dagger$ & $U S A$ \\
\hline $\begin{array}{l}\text { (a) Diseases of bones and } \\
\text { organs of movement } \\
(710-738)\end{array}$ & $\begin{array}{l}\text { Spells of sickness } \\
\text { incapacity } \\
\text { Disability or invalidity } \\
\text { Hospital discharges }\end{array}$ & $\begin{array}{l}\mathbf{M} \\
\mathbf{F} \\
\mathbf{M} \\
\mathbf{F} \\
\mathbf{M} \\
\mathbf{F}\end{array}$ & $\begin{array}{r}\bar{Z} \\
\overline{11} \cdot 7 \\
16 \cdot 3 \\
3 \cdot 1 \\
3 \cdot 1\end{array}$ & 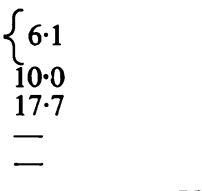 & $\begin{array}{l}13 \cdot 4 \\
10 \cdot 5 \\
11 \cdot 1 \\
17 \cdot 8 \\
=\end{array}$ & $\begin{array}{r}11 \cdot 3 \\
7 \cdot 3 \\
14 \cdot 5 \\
17 \cdot 7 \\
4 \cdot 9 \\
3 \cdot 6\end{array}$ & $\begin{array}{l}8.0 \\
= \\
\overline{-} \\
3.9 \\
2.9\end{array}$ & $\begin{array}{l}- \\
\bar{Z} \\
\overline{4 \cdot 1} \\
3 \cdot 2\end{array}$ \\
\hline $\begin{array}{l}\text { (b) Arthritis and } \\
\text { rheumatism (710-718) }\end{array}$ & $\begin{array}{l}\text { Spells of sickness } \\
\text { incapacity } \\
\text { Disability or invalidity }\end{array}$ & $\begin{array}{l}\mathbf{M} \\
\mathbf{F} \\
\mathbf{M} \\
\mathbf{F}\end{array}$ & $\begin{array}{l}\bar{Z} \\
\bar{Z}\end{array}$ & $\left\{\begin{array}{r}3 \cdot 5 \\
4 \cdot 6 \\
9 \cdot 7\end{array}\right.$ & $\begin{array}{l}6 \cdot 6 \\
5 \cdot 5 \\
10 \cdot 1 \ddagger \\
16 \cdot 8 \ddagger\end{array}$ & $\begin{array}{l}\overline{\overline{1}} \\
15 \cdot 1 \\
15 \cdot 2\end{array}$ & $\frac{4 \cdot 8}{13 \cdot 3}$ & $\bar{E}$ \\
\hline
\end{tabular}

* After Benn (1971).

† Data for sickness incapacity relate to Great Britain, for disability or invalidity to England, and for hospital discharges to England and Wales. $\ddagger$ Includes data on displacement of intervertebral disc.

Table V Death rates per million living from various rheumatic conditions in selected countries in 1966 Rates standardized to the population of England and Wales

\begin{tabular}{|c|c|c|c|c|c|}
\hline \multirow[t]{2}{*}{ Continent } & \multirow[t]{2}{*}{ Country } & \multicolumn{2}{|c|}{ Rheumatic fever (A79) } & \multicolumn{2}{|c|}{ Arthritis and spondylitis (A122) } \\
\hline & & Male & Female & Male & Female \\
\hline America & $\begin{array}{l}\text { Argentina } \\
\text { Canada } \\
\text { Chile } \\
\text { Colombia } \\
\text { Mexico } \\
\text { USA }\end{array}$ & $\begin{array}{r}4 \cdot 3 \\
1 \cdot 4 \\
5 \cdot 5 \\
12 \cdot 6 \\
3 \cdot 4 \\
2 \cdot 6\end{array}$ & $\begin{array}{r}8 \cdot 3 \\
0 \cdot 8 \\
14 \cdot 9 \\
19 \cdot 4 \\
12 \cdot 0 \\
2 \cdot 6\end{array}$ & $\begin{array}{r}6.8 \\
11.9 \\
9.9 \\
19 \cdot 5 \\
11 \cdot 1 \\
9.0\end{array}$ & $\begin{array}{l}14 \cdot 1 \\
29 \cdot 2 \\
22 \cdot 4 \\
41 \cdot 8 \\
31 \cdot 7 \\
18 \cdot 6\end{array}$ \\
\hline Asia & $\begin{array}{l}\text { China (Taiwan) } \\
\text { Japan } \\
\text { Philippines }\end{array}$ & $\begin{array}{l}14 \cdot 6 \\
5 \cdot 8 \\
18 \cdot 5\end{array}$ & $\begin{array}{l}31 \cdot 1 \\
11 \cdot 5 \\
10 \cdot 4\end{array}$ & $\begin{array}{l}23 \cdot 8 \\
22 \cdot 1 \\
21 \cdot 4\end{array}$ & $\begin{array}{l}62 \cdot 2 \\
61 \cdot 5 \\
13 \cdot 7\end{array}$ \\
\hline Europe & $\begin{array}{l}\text { Austria } \\
\text { Belgium } \\
\text { Czechoslovakia } \\
\text { Denmark } \\
\text { Finland } \\
\text { France } \\
\text { Germany (Federal Republic) } \\
\text { Greece } \\
\text { Hungary } \\
\text { Ireland } \\
\text { Netherlands } \\
\text { Norway } \\
\text { Poland } \\
\text { Portugal } \\
\text { Sweden } \\
\text { Switzerland } \\
\text { UK\{ }\left\{\begin{array}{l}\text { England and Wreland } \\
\text { Scotland }\end{array}\right. \\
\text { Yugoslavia }\end{array}$ & $\begin{array}{l}1 \cdot 4 \\
4.1 \\
3 \cdot 8 \\
(0 \cdot 4) \\
2 \cdot 7 \\
3 \cdot 0 \\
2 \cdot 2 \\
3 \cdot 1 \\
1 \cdot 5 \\
3 \cdot 9 \\
1 \cdot 2 \\
(0.6) \\
19 \cdot 3 \\
5 \cdot 0 \\
(0 \cdot 4) \\
(0 \cdot 4) \\
1 \cdot 8 \\
(6 \cdot 6) \\
(0.4) \\
1 \cdot 2\end{array}$ & $\begin{array}{c}1 \cdot 5 \\
4 \cdot 7 \\
8 \cdot 3 \\
(1 \cdot 1) \\
(1 \cdot 4) \\
2 \cdot 0 \\
3 \cdot 6 \\
2 \cdot 6 \\
1 \cdot 1 \\
(2 \cdot 4) \\
1 \cdot 1 \\
-\quad \\
28 \cdot 9 \\
2 \cdot 4 \\
-\quad 1.8 \\
1.8 \\
10.5 \\
(0.4) \\
0.6\end{array}$ & $\begin{array}{r}18 \cdot 0 \\
12 \cdot 4 \\
8 \cdot 4 \\
13 \cdot 1 \\
21 \cdot 8 \\
8 \cdot 8 \\
19 \cdot 3 \\
10 \cdot 3 \\
6 \cdot 7 \\
20 \cdot 4 \\
11 \cdot 7 \\
9 \cdot 0 \\
27 \cdot 0 \\
4 \cdot 8 \\
11 \cdot 5 \\
17 \cdot 2 \\
14 \cdot 3 \\
18 \cdot 8 \\
13 \cdot 1 \\
1 \cdot 2\end{array}$ & $\begin{array}{r}41 \cdot 5 \\
22 \cdot 6 \\
31 \cdot 9 \\
39 \cdot 5 \\
69 \cdot 8 \\
21 \cdot 6 \\
46 \cdot 8 \\
21 \cdot 7 \\
24 \cdot 4 \\
36 \cdot 4 \\
34 \cdot 9 \\
24 \cdot 2 \\
63 \cdot 6 \\
6 \cdot 2 \\
32 \cdot 1 \\
47 \cdot 2 \\
40 \cdot 0 \\
42.0 \\
39 \cdot 6 \\
3.5\end{array}$ \\
\hline Oceania & $\begin{array}{l}\text { Australia } \\
\text { New Zealand }\end{array}$ & $\begin{array}{l}1 \cdot 3 \\
3 \cdot 6\end{array}$ & $\begin{array}{l}1 \cdot 0 \\
4 \cdot 1\end{array}$ & $\begin{array}{l}13 \cdot 8 \\
11 \cdot 1\end{array}$ & $\begin{array}{l}34 \cdot 4 \\
46 \cdot 0\end{array}$ \\
\hline
\end{tabular}

Source: World Health Statistics Annual for 1966 (1969).

Rates are shown in italics when derived from less than 20 deaths, and are additionally enclosed in parentheses when derived from less than 5 deaths.

cases, 13:1. These findings appeared to be consistent with the observation of Logan (1963) that Japan had the lowest crude death rate from RA in the whole world.
A review of world-wide mortality was prompted by the observation that more recent data were less consistent. In fact, Japan had one of the highest death rates. The review had to be restricted to those 
countries that reported data to WHO in such a form that the A list of 150 causes for tabulation of morbidity and mortality could be used; the abbreviated B list of 50 causes does not separately identify any rheumatic complaint apart from rheumatic fever. The review was then limited further to those countries experiencing twenty or more deaths from arthritis and spondylitis (A122) in at least one of the two sexes.

The results set out in Table $\mathrm{V}$ show rather less variation than was noted by Logan (1963). Whereas he reported a range of 1 to 45, the standardized rates for arthritis and spondylitis for 1966 vary between 7 and 70. For what the information is worth, Argentina now seems to have the most favourable experience, followed by the U.S.A., and with Greece holding pride of place in Europe. With the exception of women in the Philippines, Asian countries seem to have the worst mortality experience, and this is equalled in Europe by Finland and Poland.

As far as rheumatic fever is concerned, the data are far less satisfactory; for half the countries the numbers of deaths were less than twenty, and for almost a quarter they were less than five in at least one sex. Bearing in mind the relationship this disease has to the country's stage of development, the noteworthy feature is the exceptionally high rate in Poland. The rate in women in Czechoslovakia also appears unusually high.

Table VI compares prevalence estimates and death rates for those countries whence suitable data are available. The countries are ranked in descending order of magnitude of the prevalance estimates. The ranking is similar for death rates, though Czechoslovakia is exceptional in females and Japan in both sexes.

The conclusions to be drawn from these observations are as follows: (i) The ratio of death rates in the two sexes is broadly similar in the six countries $(2.9 \pm 0.6)$, and corresponds closely with clinical impressions of the female preponderance of cases.

(ii) This suggests that the disease spectrum, certainly so far as sex distribution is concerned, is probably fairly stable throughout the world.

(iii) If the ranking of prevalence estimates is discrepant with that for death rates, the advantage probably lies with the latter, in view of the large denominators and the availability of data from successive years.

By this criterion, the exceptionally low prevalence reported from Japan, so much at variance with the high death rates, certainly requires explanation. The relatively low prevalence in Czechoslovakia is also not entirely satisfactory in view of the discrepant death rate in females.

(iv) Prevalence estimates derived from surveys reporting an anomalous sex ratio for cases should also be interpreted with caution because of the apparent uniformity in sex ratios for death rates.

Noteworthy in this regard are the enormous excess of female cases in the Japanese surveys and the excess of male cases in the German survey.

(v) As no explanation for these variations can be offered, one must conclude that problems of technique loom large, particularly the lack of standardization. The approach adopted in this review may also be useful in indicating whether an anomalous sample, such as a cultural isolate, has been studied. Unfortunately, we thus seem to be as far away as ever from identifying interesting areas of abnormally low or abnormally high prevalence.

Table VI Estimates of rheumatoid arthritis in different countries*

\begin{tabular}{|c|c|c|c|c|c|}
\hline Country & $\begin{array}{l}\text { Prevalence } \\
\text { (per cent.) }\end{array}$ & $\begin{array}{l}\text { Ratio of rates } \\
\text { in the sexes } \\
\text { (Female: Male) }\end{array}$ & $\begin{array}{l}\text { Stana } \\
\text { Male }\end{array}$ & $\begin{array}{l}\text { ed death rate } \\
\text { Female }\end{array}$ & $\begin{array}{l}\text { Ratio of rates } \\
\text { in the sexes } \\
\text { (Female: Male) }\end{array}$ \\
\hline $\begin{array}{l}\text { Finland } \\
\text { Germany (Federal Republic) } \\
\text { UK(Leigh and England and Wales) } \\
\text { USA (Tecumseh) } \\
\text { Czechoslovakia } \\
\text { Japan }\end{array}$ & $\begin{array}{l}7 \cdot 5 \\
5 \cdot 7 \\
4 \cdot 0 \\
2 \cdot 5 \\
1 \cdot 3 \\
0 \cdot 4\end{array}$ & $\begin{array}{r}2 \cdot 5 \\
0 \cdot 5 \\
2 \cdot 1 \\
4 \cdot 7 \\
1 \cdot 5 \\
13 \cdot 8\end{array}$ & $\begin{array}{r}21 \cdot 8 \\
19 \cdot 3 \\
14 \cdot 3 \\
9 \cdot 0 \\
8 \cdot 4 \\
22 \cdot 1\end{array}$ & $\begin{array}{l}69 \cdot 8 \\
46 \cdot 8 \\
40 \cdot 0 \\
18 \cdot 6 \\
31 \cdot 9 \\
61 \cdot 5\end{array}$ & $\begin{array}{l}3 \cdot 2 \\
2 \cdot 4 \\
2 \cdot 8 \\
2 \cdot 1 \\
3 \cdot 8 \\
2 \cdot 8\end{array}$ \\
\hline
\end{tabular}

* Prevalence relates to probable and definite cases by the ARA criteria and is derived from Wood (1970). Death rates relate to arthritis and spondylitis (A122).

\section{References}

BENN, R. T. (1971) 'The Epidemiology of Rheumatic Complaints', ed. P. H. N. Wood, Regional Office for Europe, World Health Organisation, Copenhagen (Annex II Sickness and disability due to rheumatic complaints)

Department of Health and Social Security (DHSS) and Office of Population Censuses and Surveys (OPCS) (1970) Report on Hospital Inpatient Enquiry for the year 1967. H.M.S.O. London 
Kellgren, J. H. (1966) Arthr. and Rheum., 9, 658 (Epidemiology of rheumatoid arthritis)

Logan, W. P. D. (1963) 'The Public Health Aspects of Chronic Rheumatoid Arthritis and Related Diseases', p. 3. Regional Office for Europe, World Health Organisation, Copenhagen (Epidemiological studies of rheumatoid arthritis)

OfFice OF HEALTH Economics (1969) Information Sheet, no. 7 (The cost of diseases)

SAINSBURY, S. (1970) 'Registered as Disabled,' Occasional Papers on Social Administration, no. 35. Bell, London

Statistical Appendix (1970) Ann. rheum. Dis., 29, 324 (Digest of data on the rheumatic diseases: 2. Recent trends in sickness absence and mortality)

Wood, P. H. N. (1970) Proc. roy. Soc. Med., 63, 189 (Epidemiology of rheumatic disorders: Problems in classification) 